\title{
The Association between Attitude towards the Implementation of Staff Development Training and the Practice of Knowledge Sharing Among Lecturers
}

\author{
Abd. Latif Kassim ${ }^{1}$, Arumugam Raman ${ }^{1}$, Yahya Don $^{1}$, Yaakob Daud ${ }^{1} \&$ Mohd Sofian Omar ${ }^{1}$ \\ ${ }^{1}$ School of Education and Modern Languages, Universiti Utara Malaysia, Sintok, Kedah, Malaysia \\ Correspondence: Arumugam Raman, School of Education and Modern Languages, Universiti Utara Malaysia, \\ Sintok, Kedah, Malaysia. Tel: 60-4928-5409. E-mail: arumugam@uum.edu.my
}

Received: May 18, 2015 Accepted: June 30, 2015 Online Published: November 25, 2015

doi:10.5539/ies.v8n12p108 URL: http://dx.doi.org/10.5539/ies.v8n12p108

\begin{abstract}
This study was aimed to identify the association of teachers' attitude towards the implementation of Staff Development Training with Knowledge Sharing Practices among the lecturers of the Teacher Training Instituition (TTI). In addition, this study was also to examine the differences in attitudes towards the implementation of Staff Development Training and differences of knowledge sharing practices of lecturers based on demographic factors (gender, teaching experience, and academic qualifications). This is a quantitative approach in cross-sectional survey to collect data on the attitude towards staff development training and knowledge sharing practices among lecturers. The population of this study involved 748 lecturers from TTI in Perlis, Kedah, and Pulau Pinang. Stratified random sampling technique was used to select 336 samples from the population. The instruments used in this research were Attitude of Staff Development Training (Siti-Zanariah, 2010) and Knowledge Sharing (Siti-Zanariah, 2010). Statistical Package for Social Science (SPSS) Version 19.0 was used for analysis of data. The descriptive data analysis involved the description of the respondents such as frequency and percentage, while the second part of inferential analysis was to test the hypotheses, using Pearson correlation, t-test, and ANOVA. This study had found that there was a significant and positive association between attitude towards SDT with knowledge sharing practices, a significant difference and positive attitude towards SDT based on gender and teaching experience and a significant and positive difference in terms of knowledge sharing practices based on gender, teaching experience, and academic qualifications. However, the results revealed that there were no significant differences in the attitudes of SDT based on academic qualifications. This research also discussed about the findings, implications, and contributions to the body of knowledge and the country, as well as the direction of future research.
\end{abstract}

Keywords: attitude, staff development, practice of knowledge, teacher training, lecturers

\section{Introduction}

Since the late 1980s, public sector organizations in Malaysia have begun to recognize the need to improve the quality of management and service staff. This situation is illustrated by the launch of the Excellent Work Culture Movement on 27 November 1989. The movement stressed the importance of organizational learning practices through the implementation of an active staff development program to ensure they have the knowledge and skills to meet the challenges of the changing environment (Malek-Shah, 2005).

The Government also always concerned about the quality of service of the citizens and public sector organizations to the establishment of the National Integrity Plan in April 2004, which emphasizes values when working as ethical behavior and teamwork (Malek-Shah, 2005; Sta.-Maria, 2002). Thus, the government's aim will only be achieved if an organization is capable of moving towards developing a learning organization. This is because only individuals who are knowledgeable and highly skilled who seek to change, and this is where employees are encouraged to adopt a positive attitude and be able to share the knowledge and skills acquired (Kanter, 2001), particularly among staffs of public sector organizations such as the education sector which always attract the attention of the public.

However, in recent years, the effectiveness of the quality program among public sector organizations in Malaysia is less favorable (Boon \& Fadzlon, 2011). This failure stems from their own attitude in which the concept of 
quality that is emphasized is difficult to be understood by them and still they lack the initiative to understand. This phenomenon results in a positive culture that resists change and lack of knowledge sharing and disclosure of relevant changes in terms of knowledge and skills (Stephen, 1990). In addition, work culture of public sector organizations are emphasizing the duties, discipline, strict procedures, and strict work rules, in addition to less space for creative (Kline \& Saunders, 2006). This implicating work culture has created a gap between the top and subordinates as well as between colleagues of different fields, thus, preventing them to share their knowledge and skills (Boon \& Fadzlon, 2011).

\subsection{Objectives}

The main objective of this study was to examine the implementation of Staff Development Training (SDT) as a tool for knowledge sharing among lecturers in Teacher Education Institutions (TTI). In particular, this study aims to:

i. Identify the lecturer's attitude towards the implementation of SDT in TTI.

ii. Identify the level of knowledge sharing practices among lecturers in TTI.

iii. Identify the relationship between attitude towards SDT and practice of knowledge sharing among lecturers in TTI.

\section{Literature Review}

Having an agenda in educational research to ensure there is an appropriate ethos towards increasing knowledge sharing practices among the lecturers. This is because there is still no research in Malaysia is trying to assess the extent of attitudes towards Staff Development Training (SDT) implemented by educational organizations such as TTI.

\subsection{Attitudes}

The researchers concluded attitude as an internal willingness to act when confronted with certain objects or situations that favored or vice versa (W. W. Lambert \& W. E. Lambert, 1973; Sarnoff, 1970; Boskamp, 1977)

\subsection{Staff Development Training (SDT)}

According Juhary (2000), SDT is the efforts undertaken specifically and composed by organizations to improve the knowledge of the coaches so that they can do better in their job. Siti-Zanariah (2010) also defines SDT as a multidimensional process that contains aspects of the exercise beginning with the inventory activity, practice and guidance. SDT is to design, implement and manage training programs in service to ensure staffs can perform tasks with full commitment, ethical and integrity. So, in sum, it can be formulated that SDT is all forms of training, courses, seminars, workshops, conferences, training activity, and forums that are controlled by sectors, center or office in TTI, office or unit in TTI or private institutions or other agencies.

\subsection{Motivation Theory-Based Behavior}

In the context of this study, namely Pavlov's motivation theory-based behavioral theory is the most suitable to be relied. In addition to theoretical knowledge sharing practices, social exchange theory is to be discussed in the next section which is directly related to the knowledge sharing. According to the recommendations of motivation theory of Pavlov (1927) which is based on behavior, learning process will occur easily when there is a relationship between stimulus and response. Application of this theory can be applied in the context of Staff Development Training program (SDT) developed by In-Service Training Unit of TTI. Pavlov (1927) argues that learning can occur as a result of the interplay between stimulus and response. Eventually, the lecturers will be familiar with the teaching techniques and this can be shared and set as an example to other lecturers.

\subsection{Knowledge Sharing Practices}

According Faizuniah and Aizzat (2009), knowledge sharing is an activity that is very important in knowledge management that allows more knowledge to be generated, collected and used by others. According to McNeil (2003) practice knowledge sharing is an important element in management science. It is usually occur when individuals who shares the same goals and experiences to exchange views and information. Knowledge sharing between individuals involves the exchange of information by a person to a kind of information that can be understood, absorbed and used by others. The practice of knowledge sharing can also be defined as the actions of individuals who make knowledge available to him or her and also to be understood by other members who served in the same organization (Ipe, 2003). According to Bartol and Srivastava (2002) knowledge sharing involves sharing information, ideas, suggestions, and expertise between one individual to another individual. 


\subsection{Attitudes toward Implementation Staff Development Training and Knowledge Sharing Practices}

Reviews from Azizah, Hamida, and Sheau (2009) found that non-academic staff of Universiti Teknologi Malaysia were aware of the purpose of training and understand the importance of such training in the performance of their work at workplace. The findings also showed that workers need to have an awareness of the objectives, needs and interests of exercise in improving the implementation of their work in the workplace. This is because individuals who have a high level of commitment to the job will place a high value on training and further more committed when there is an opportunity to learn or share new skills and knowledge. Review by Henze, Van Driel, and Verloop (2009) on learning strategies of experienced teachers in the context of educational innovation also found that teachers tend to learn individually and collaboratively by several methods such as from other teachers, swap stories, help tools, ideas and practices as well as sharing knowledge and skills. One of the previous studies on the relevance of SDT by Ab. Razak (2000) seeks to identify the impact of staff development programs on job performance of teacher training college lecturers in Malaysia. Research is conducted to identify the extent to which staff development programs which have been followed by the lecturers able to affect the performance of their work, from the aspect of knowledge, attitudes, and skills. 246 lecturers showed that there is a significant relationship between planning and implementation of staff development programs with job performance of lecturers including practice of sharing and exchange of knowledge.

Richter, Kunter, Klusmann, Ludtke, and Baumert (2011) conducted a study related to learning opportunities for formal and informal professional development of teachers. The study involving a total of 1939 teachers showed formal learning opportunities such as training and in-service courses are more widely used by teachers at the middle level of service. Meanwhile, informal learning is used by teachers at all levels of services such as knowledge sharing and exchange of ideas. This indirectly shows the relationship between formal and informal learning with teacher development stage.

Mohd, Abdul, and Zulkifli (2006) conducted a survey about relationships, motives, attitudes as well as teacher training and professionalism in teaching final year university students who pursued education program. It was aimed to identify the direct and indirect motives, attitudes, and teacher training and professionalism in teaching final year university students who pursued education program. The study involved 650 final year students undergoing education program in a local university. Results showed that the variables such as motives, attitudes, and teacher training were directly correlated with professionalism among respondents' year and education programs in universities. This assertion is supported by Boon Pong Ying (2004) who argued that to strengthen professionalism, an educator who has attended courses or training exercises should have learned it in their schools, in addition to sharing the knowledge gained with other partners so that other educators can gain knowledge and skills in specific areas.

Review by Azlah, Mohamad, Thahiroh, and Thuaibah (2009) relates the effectiveness of training among support staff in the Office of the State Secretary of Kedah Darul Aman. The objective of the study is to identify respondents' perceptions of the effectiveness of training programs conducted from the aspect of reactions as well as to identify respondents' perceptions of the effectiveness of training on learning and behavioral aspects. The study involved 78 staff members of support groups from Kedah State Secretary's Office at Wisma Darul Aman. The support groups are derived from 3 sections; Housing Division, Human Resources, and Finance Division. Analysis showed that the perception regarding the assessment of the effectiveness of the training program reaction ratio is at a high level.

The findings of Azlah et al. (2009) was further strengthened by the results of the study by Ilhaamie (2011), which indicated that employee attitudes need to be changed to get higher productivity of their work and the Human Resources Department plays an important role in improving employee motivation, namely to carry out training for staff development. According to the researchers, the organization that uses innovative training practices is more visible and has potential to be financially sound compared with other organizations. The result of research showed that employees must have an understanding and knowledge that enable them to monitor and improve the quality of services and products. It can be achieved with the existence of the practice and staff development training in the organization that has its own influence and can encourage employees to learn, gain knowledge and share that knowledge together with other colleagues in the organization.

\section{Methodology}

The aim of this study is to examine the relationship of TTI lecturers' attitudes with the effectiveness of SDT in terms of knowledge sharing. This is a quantitative study by applying a cross-sectional survey (cross-sectional survey) based on a questionnaire answered by the respondents. The population for this study consisted of lecturers from TTI from Northern states including Perlis, Kedah and Penang. Population consists of 748 lectures. 
The sample size was selected based on recommendations by Krejcie and Morgan (1970). Therefore a total of 336 lecturers were chosen as respondents for this study. Stratified random Sampling technique was used in this study (Barbie, 1990) in which the TTI's from the North Zone were grouped according to their respective states. The first step was to identify and list the TTI's found in three states namely Perlis, Kedah and Penang. Next, several TTI's were shortlisted from the list. The researchers used Random Number Schedule to get the 336 respondents who participated in this study.

Overall, the instrument used to measure the variables is a standard instrument that was developed and adopted in western countries. This instrument was divided into three parts: Part A: The questionnaire for demographic information, which contained seven items. Part B: The questionnaire on Attitudes towards SDT (Siti-Zanariah Ahmad, 2010) which contains 28 items. Items included information related to the SDT that covers the implementation, the process and results of SDT. Cronbach Alpha showed high reliability of between 0 and 1 for all 28 items. Part C: The questionnaire for Knowledge Sharing (Siti-Zanariah, 2010) that consists of 22 items. Respondents are required to choose whether they agree or disagree by circling the statement. Likert scale was used in order to get a more precise answer and to save time. Questionnaire was adapted and modified from the questionnaires completed by Siti-Zanariah (2010) who modified the instrument of Canaa et al. (2000) for a research related to knowledge sharing among teachers.

In this study, the reliability of the study was referred to the two variables studied; the attitudes towards SDT and practice of knowledge sharing. For the variable attitudes towards SDT, the alpha value obtained was high at a $=.96$ whereas alpha value of $a=.95$ was obtained for practice of knowledge sharing. Both alpha values are can be adopted in this study. Validity of the study referred to the consistency of the measurement tools built (Hardy \& Bryan, 2004; Lokman et al., 2008). It was determined by factor analysis to obtain the construct validity. Correlation values for scores of items that can be accepted as the values are the value that exceeds 0.25 (Nunally \& Beirstein, 1994; Lokman et al., 2008).

To analyze data, inferential statistics was used to test the hypotheses that have been formed. Pearson correlation analysis was used to examine the relationship between attitudes towards SDT with knowledge sharing practices.

\section{Results}

In terms of gender, male respondents $204(60.7 \%)$ are more than female respondents $132(39.3 \%)$. Furthermore, the findings also showed that a total of $28(8.3 \%)$ of the respondents aged between 30-39 years, $112(33.3 \%)$ aged between 40-49 years, and a total of 196 respondents were more (58.3\%) aged between 50-59 year. Meanwhile, if viewed in terms of race, a total of $288(85.7 \%)$ of the respondents were Malays, $28(8.3 \%)$ were Chinese, and about 20 others (6.0\%) were Indians.

\subsection{TTI Lecturer's Attitude towards Implementation of SDT}

All items assessed using descriptive statistics of percentage, mean and standard deviation. Based on the results of the descriptive analysis in the overall attitude towards the implementation of SDT obtained is at a high level (mean $=4.09, \mathrm{SD}=.48)$.

\subsection{Level of Knowledge Sharing Practices}

To identify the extent of knowledge sharing practices through the implementation of SDT on the TTI lecturers, descriptive statistics were used. The findings indicted that the average mean of the practice of knowledge sharing was at 4.41 with a standard deviation of .40 .

\subsection{Testing Hypothesis}

The relationship between lecturer's attitude and knowledge sharing practices towards SDT.

Pearson correlation analysis was conducted to determine if there is a significant relationship between the attitudes towards SDT and practice of knowledge sharing among lecturers at TTI.

Table 1. Correlation between the attitude towards SDT and practice of knowledge sharing among Lecturer TTI

\begin{tabular}{cccc}
\cline { 2 - 4 } Variable & Attitude & Practice \\
\cline { 2 - 4 } & Attitude & 1 & $0.595^{* *}$ \\
Practice & $0.595^{* *}$ & 1 \\
\hline
\end{tabular}


Based on the results of Table 1 above, a significant relationship was found at $p<0.05$ between the attitude towards SDT with knowledge sharing practices $(r=0.595 ; \mathrm{p}<0.05)$ among lecturers at TTI. The results of this correlation analysis, thus supporting the null hypothesis that there is a significant and positive relationship between attitude towards SDT and knowledge sharing practices $(\mathrm{r}=0.595 ; \mathrm{p}<0.05)$ among lecturers at TTI.

\section{Discussion}

The findings showed that a positive attitude towards SDT was found and could improve knowledge sharing practices among lecturers at TTI. The results of this study are consistent with findings of Siti-Zanariah (2010), Azlah et al. (2009), Nadler (1986), and Blanchard (2004), which were generally found that there is a significant and positive relationship between attitudes toward SDT with practice of knowledge sharing. However, these findings contradict with the results of a study by Henze et al. (2009) that there was no significant relationship between attitude towards SDT and practice of knowledge sharing. According to Cascio (1989), training in SDT consists of a planned program that is designed for performance improvement at individual, group, and organization level. In fact, the improved performance contained an implicit element of expectations and assessments that were there changes that can be measured in terms of knowledge, skills, attitudes and social behavior of individuals. Further justification was based on the fact stressed by Naim (2004) which stated that the sharing of knowledge is a social process in which individuals share their experience and knowledge that is not real like sharing mental models and other technical skills.

\subsection{Implications of Study}

Overall, this study supports the fact that attitude influences the implementation of SDT in the development of knowledge sharing practices among lecturers at TTI. Further, the theoretical implications and implication of practice are also observed in this study.

\subsubsection{Theoretical Implications}

Academic implications of this study can be seen in terms of the appropriateness of the questionnaire and the theory used. Overall, the instrument used is satisfactory and has high reliability and validity. Back to back translation method was used in addition to pilot test to contribute to the strengthening of the reliability and validity of this instrument. This aspect may indirectly support the opinion of scholars who claim that the instruments developed in western countries can be applied in the context of local communities with specific measures to suit the conditions and culture of the society in Malaysia. The study has also contributed to the theories of motivation, namely behavior-based theory (Pavlov, 1927) and social exchange theory (Blau, 1964) which are used as the base to design the framework of this study. Behavior-based theory predicts that the learning process will occur easily when there is a relationship between stimulus and response. Through this study of relationship between attitude towards SDT and knowledge sharing practices, it is observed that training related to the duties and exercising the framework of the preparation undertaken regularly can help in building a positive stimulus. This may increase the response of individuals positively into the effectiveness of training (Ibrahim, 2001), because this is also to be expressed by In-Service Training Unit in TTI, through the implementation of SDT on lecturers and staff involved. So, not surprisingly, the results of this study support the prosecution's theory of behavior based upon the results shown that there is a significant and strong correlation between attitude towards the implementation of SDT and practice of knowledge sharing among lecturers at TTI.

\subsubsection{Implications of Practice}

The results of this study also provide an important contribution to the body of knowledge, particularly to the administrator and the Human Resources Division of TTI. It can be seen from the context of attitude towards the implementation of SDT and practice of knowledge sharing among lecturers of TTI. Overall, the results showed that there was a significant and strong correlation between attitudes towards the implementation of SDT and practice of knowledge sharing among lecturers. Accordingly, the variables must be taken into account as an important element in designing staff development programs in TTI and in realizing the aspirations of MECC 2013-2025 in human capital of excellence in various aspects.

The findings of this study may also help the TTI, especially in the states of Perlis, Kedah and Penang in shaping the attitudes of teachers towards SDT, improvements in performance through SDT as well as finding ways to encourage knowledge sharing practices among its staff. Among the measures that can be done is:

- TTI's should pay attention to the attitude of lecturers towards the implementation of SDT and examine the level of knowledge sharing practices practiced by them.

- Courses, training, and staff development programs should be regularly reviewed and improvements should be made from time to time in order to improve the quality of the in house training programs. 
- $\quad$ TTI's should strive to realize the importance of SDT for lecturers in improving their skills and experience in various aspects of the quality of the in house training programs in order to produce a balanced human capital in various fields.

- $\quad$ TTI's needs to send qualified lecturers to pursue their specialization to add to the new knowledge along with the development of technology today.

- $\quad$ TTI's need to cultivate and promote knowledge sharing practices among the lecturers so that the knowledge gained through SDT can be shared with other staff.

- $\quad$ The TTI's also needs to emphasize the importance of attitudes and knowledge sharing practices that should be possessed by the lecturers during the recruitment process of lecturers through the strainer-filter. Selection of lecturers should not merely based on seniority and IQ abilities, but also emphasizes the attitudes and knowledge sharing practices of the lecturers too.

- TTI's needs to assess the attitude of lecturers towards SDT by their teaching experience. Further, improvement and training should be given to produce lecturers of good quality.

- $\quad$ TTI's need to give more focus and provide more workshops to foster positive attitudes towards SDT and knowledge sharing practices, in addition to tailoring the training and activities of SDT, by gender and teaching experience of lecturers.

In addition, information on the results of this study is an important source for Ministry of Education (MOE), Human Resources, the State Education Department (SED), and other educational institutions to develop and strengthen attitudes towards implementation of SDT.

\subsection{Recommendations}

Based on the findings, recommendations for future research are to include an increase in the dimensions of the variables studied, research methods, and additional variables. This study has identified a strong relationship that exists between attitudes towards SDT with practice of knowledge sharing among TTI lecturers. And further research by focusing on the dimensions of the variables; attitude towards the implementation of SDT and practice knowledge sharing, is encouraged in the future. In addition, the methodology of the study can also be done in a larger scope, involving a larger sample, not only involving TTI in Perlis, Kedah and Penang but others as well. This study also found to contribute to the researchers to identify the different aspects of demography, particularly in terms of gender, teaching experience, and academic research. Future studies related to aspects of these demographic items are likely to be able to include the economic, cultural, placement, status, and social environments as well. The findings of this study can be used as a basis for studies related to attitudes towards SDT and knowledge sharing practices, particularly in the TTIs and other educational institutions in Malaysia. Studies like this will hopefully help unravel the secrets of an educator's attitude towards SDT and knowledge sharing practices are practiced to assist in nurturing a productive and successful individual in various aspects for the development of education in Malaysia. However, the proposed study is more like a prefix to find the relationship between the variables in empowering TTIs in Malaysia, thus achieving vision 2020.

\section{References}

Ab. Razak, A. K. (2000). Kesan program perkembangan staf terhadap prestasi kerja pensyarah maktab perguruan di Malaysia. Tesis Sarjana. UUM.

Akhtaruddin, M., \& Hasnah, H. (2010). Board ownership, audit committees' effectiveness, and corporate voluntary disclosures. Asian Review of Accounting, 18(3), $245-259$. http://dx.doi.org/10.1108/13217341011089649

Alan, H. A. (1993). Successful training practice: A manager's guide to personnel development. Oxford UK: Blackwell Business Publishers.

Anastasi, A., \& Urbina, S. (1997). Psychological testing (7th ed.). Upper Saddle River, NJ: Prentice-Hall.

Azizah, R., Hamidah, A. R., \& Kong, S. P. (2009). Development staff training for capacity building. Journal of Educational Administration, 49(6), 685-700.

Azlah, M. A., Noor, E. M. Z., Thahiroh, Z., \& Thuaibah, R. O. (2009). Keberkesanan latihan di kalangan kakitangan kumpulan sokongan di pejabat Setiausaha Kerajaan Negeri Kedah Darul Aman.

Babbie, E. (1995). The practice of social research (7th ed.). Belmont: Wadsworth Publishing Company.

Bandura, A. (1977). Self-efficacy: Toward a unifying theory of behavioral change. Psychological Review, 84, 191-215. http://dx.doi.org/10.1037/0033-295X.84.2.191 
Barbie, E. (1990). Survey research method (2nd ed.). Belmont CA: Wadsworth Publishing Company.

Bartol, \& Srivastava. (2002). Assessing the function of schools as learning organization. Children \& School, 29(4), 199-216.

Berita, H. (2005). Pembangunan modal insan usaha lahirkan graduan berdaya saing.

Blanchard, P. N., \& Thacker, J. W. (2004). Effective traning, systems, strategies and practice. New Jersey: Pearson Education Inc.

Blau, P. (1964). Power and exchange in social life. NY: John Wiley \& Sons.

Boon, P. Y. (2004). Amalan Reflektif Ke Arah Peningkatan Profesionalisme Diri Guru. Jurnal IPBA, 2, 102-109.

Canas, A. J., Leake, D. B., \& Wilson, D. C. (1999). Managing, Mapping, and Manipulating Conceptual Knowledge. In AAAI Workshop Technical Report WS-99-10: Exploring the Synergies of Knowledge Management \& Case-Based Reasoning. Menlo, CA: AAAI Press.

Cascio, W. F. (2003). Managing Human Resources: Productivity, Quality of Work Life, Profits (6th ed.). USA: McGraw-Hill.

Collins, J. C. (2001). Good to Great: Why Some Companies Make the Leap...and Others Don't. New York: Harper Business.

Dessler, G. (2005). Human Resource Management (10th ed.). New Jersey: Prentice-Hall.

Fauzuniah, P., \& Aizzat, M. N. (2009). The relationship between human resource management practices, effective commitment and knowledge sharing behavior. Tesis Doktoral tidak diterbitkan.

Garvin, D. A., Edmondson, A. C., \& Gino, F. (2008). Is yours learning organization. Harvard Business Review, $86(3), 109-116$.

Gregory. (2010). System improvement through collective capacity building. Journal of Educational Administration, 49(6), 624-636.

Hardy, M., \& Bryman, A. (Eds.) (2004). Handbook of Data Analysis. London: Thousand Oaks. http://dx.doi.org/10.4135/9781848608184

Henze, V. D., \& Verloop. (2009). Experienced science teachers' learning in the context of educational innovation. Journal of Teacher Education, 60(2), 184-199. http://dx.doi.org/10.1177/0022487108329275

Hoekstra, Brekelmans, Beijaard, \& Korthagen. (2011). Experienced teachers' informal learning: Learning activities and changes in behavior and cognition. Teaching and Teacher Education, 25(2), 663-673.

Ibrahim, M. (2001). Effective Design and Successful Management of Training. Kuala Lumpur: Eastview Publication Sdn. Bhd.

Ipe, M. (2003). Knowledge sharing on organizations: A conceptual framework. Human Resource Development Review, 2(4), 337-359. http://dx.doi.org/10.1177/1534484303257985

Ivancevich, J. M. (2007). Human Resource Management. New York: McGraw-Hill/Irwin.

Jamaliah, A. H. (2008). Knowledge strategies of school administrators and teachers. International Journal of Educational Management, 22(3), 259-268. http://dx.doi.org/10.1108/09513540810861892

Johnson, B., \& Christensen, L. (2005). Educational research: Quantitative, qualitative, and mixed approaches (2nd ed.). Boston, MA: Pearson Education Inc.

Juhary, A. (2000). Asas Pengurusan (3rd ed.). Pulau Pinang : Universiti Sains Malaysia.

Kanter, R. M. (2001). Evolve: Succeeding in the digital culture tomorrow. Boston, MA: Harvard Business School Press.

Kline, P., \& Saunders, B. (2006). Ten Steps to a Learning Organization. Salt Lake City, UT: Great River Books.

Krejcie, R. V., \& Morgan, D. W. (1970). Determining sample size for research activities. Educational ang Psychological Measurement, 30, 607-610.

Lambert, W. W., \& Lambert, W. E. (1973). Social Psychology. Englewood Cliffs, NJ: Prentice-Hall.

Lee, J. N. (2001). The impact of knowledge sharing, organizational capability and partnership quality on IS $\begin{array}{llll}\text { outsourcing success. Information and } & \text { Management, 36(5), } 335 .\end{array}$ http://dx.doi.org/10.1016/S0378-7206(00)00074-4 
Little-John, S. W. (1996). Theories of Human Communication (5th ed.). Belmont, CA: Wadsworth.

Lokman, M. T., \& Kalsom, S. (2008). Implikasi latihan dalaman kepada guru-guru sekolah rendah. Skudai: UTM.

MacNeil, C. M. (2003). Line managers: facilitators of knowledge sharing in teams. Employee Relations, 25(3), 294-307. http://dx.doi.org/10.1108/01425450310475874

Malek, S. M. Y. (2005). The public service as a learning organization. The Malaysian Experience, Internation Review of Administrative Sciences, 71(3), 463-474. http://dx.doi.org/10.1177/0020852305056824

Mohamad, N. J. (2004). The Role of leadership in promoting knowledge sharing practice in matriculating program (Ministry of Education Malaysia). Tesis Sarjana. UUM.

Mohan, B. (2008). A Chapter on South Asians in the US. Encyclopedia of Social Work, 1, 172-174.

Mohd, Y. A., Salleh, A. R., \& Zulkifli, M. (2006). Kekuatan hubungan motif, sikap dan latihan perguruan dengan profesionalisme keguruan pelajar tahun akhir program pendidikan IPTA. Sabah: Sekolah Pendidikan dan Pembangunan Sosial, Universiti Malaysia Sabah.

Nadler, A. (1986). Self Esteem and Help Seeking and Receiving: Empirical and theoretical perspectives. New York: Academic.

Norasmah, O., Mohd, I. H., \& Zuraidah, A. (2010). Pengaruh amalan pengurusan sumber manusia (PSM) terhadap hasil PSM di IPTS bukan bertaraf universiti. Jurnal Pengurusan, 31, 43-53.

Nunnally, J. C., \& Bernstein, I. H. (1994). Psychometric Theory. NY: McGraw-Hill.

Obadara, O. (2013). Relationship between distributed leadership and sustainable school improvement. Nigeria: Department of Educational Management Tai Solarin University of Education.

Orlikowski, W. (2002). Organizational transformation over time. Information System reseacrh, 7(1), 63-92. http://dx.doi.org/10.1287/isre.7.1.63

Pavlov, I. P. (1927). Conditioned Reflexes: An investigation of the physiological activity of the cerebral cortex (translated by G. V. Anrep). London: Oxford University Press.

Postholm. (2011). A completed research and development work project in school: the teachers' learning and possibilities, premises and challenges for further development. Teaching and Teacher Education, 27, 560-568. http://dx.doi.org/10.1016/j.tate.2010.10.010

Richter, Kunter, Klusmann, Ludtke, \& Baumert. (2011). Professional development across the teaching career: Teachers' uptake of formal and informal learning opportunities. Teaching and Teacher Education, 27, 116-126. http://dx.doi.org/10.1016/j.tate.2010.07.008

Ricks, B. R., Ginn, M. L., \& Daughtrey, A. S. (1995). Contemporary Supervision (2nd ed.). New York: Mcgraw Hill.

Ryu, S., Ho, S. H., \& Han, I. (2003). Knowledge sharing behavior of physicians in hospitals. Expert Systems with Applications, 1, 113-122. http://dx.doi.org/10.1016/S0957-4174(03)00011-3

Sarnoff, I. (1970). Social Attitudes and the Resolution of Motivational Conflict. Harmondsworth: Penguin.

Siti-Zanariah, A. (2010). Hubungan sikap terhadap pelaksanaan latihan dalam perkhidmatan (LDP) dengan amalan perkongsian ilmu dalam kalangan guru: Satu kajian kes. Tesis Sarjana. UUM.

Sta.-Maria, R. F. (2002). Learning for a Change: A Guide to Developing Learning Cultures in the Malaysian Public Sector. Kuala Lumpur: INTAN.

Stephen, R. C. (1990). The 7 Habits of Highly Effective People. USA: Simon \& Schuster.

Supian, H., \& Khadijah, D. (2012). Amalan kepimpinan lestari dan hubungannya dengan prestasi kerja guru sekolah rendah yang menerima tawaran baru di daerah Segamat. Tesis Sarjana. UTM.

Truelove, S. (1995). The Handbook of Training and Development (2nd ed.). UK: Blackwell Bussiness.

Van Hooser, P. (1998). A four-level learning organization benchmark implementation model. The Learning Organization, 10(2), 98-105.

Yusof, B., \& Fadzlon, H. (2011). Tahap amalan organisasi pembelajaran di sebuah sekolah menengah daerah Kulaijaya, Johor. Journal of Education Management, 4, 18-33.

Zaimah, A. (2012). Pembentukan komuniti pembelajaran profesional: Kajian terhadap sekolah menengah di 
Malaysia. Jurnal Managemen Pendidikan, 5(2), 78-96.

\section{Copyrights}

Copyright for this article is retained by the author(s), with first publication rights granted to the journal.

This is an open-access article distributed under the terms and conditions of the Creative Commons Attribution license (http://creativecommons.org/licenses/by/3.0/). 